\title{
AKTIVITAS ANTIBAKTERI FRAKSI-FRAKSI EKSTRAK SIRIH HIJAU (Piper betle Linn) TERHADAP PATOGEN PANGAN
}

\author{
[Antibacterial Activity of Fractionated Green Sirih (Piper betle Linn) \\ Extract Against Food Pathogenic Bacteria]
}

\author{
Suliantari*, Betty S. L. Jenie, dan Maggy T. Suhartono \\ Departemen Ilmu dan Teknologi Pangan, Fakultas Teknologi Pertanian, Institut Pertanian Bogor, Bogor
}

Diterima 13 November 2010 / Disetujui 17 Desember 2012

\begin{abstract}
Fractionation of green sirih (Piper betle Linn) extract by chromatography colom using the mixture of several solvents i.e. chloroform, ethanol and acetic acid (4:1:1) resulted in 17 fractions. All fractions showed antibacterial activities but only 2 fractions (fraction 3 and fraction 4) showed the highest inhibition towards the six tested bacteria Escherichia coli, Salmonella Typhimurium, Pseudomonas aeruginosa, Staphylococcus aureus, Bacillus cereus and Listeria monocytogenes. Among the tested bacteria, all fractions of green sirih extracts showed the most effective inhibition against, Salmonella Typhimurium with inhibition zone diameters ranging from $10 \mathrm{~mm}$ to $26 \mathrm{~mm}$. Identification using GC-MS found that fraction 3 and fraction 4 contained chavicol; dodecanoic acid, myristic, palmitic and oleic acid.
\end{abstract}

Keywords: antimicrobial, fractionation, pathogen, green sirih

\section{ABSTRAK}

Fraksinasi ekstrak etanol sirih hijau (Piper betle Linn) dengan kromatografi kolom pada silika gel dengan eluen kloroform, etanol dan asam asetat menghasilkan 17 fraksi yang umumnya mempunyai aktivitas antibakteri tetapi hanya dua (2) fraksi yaitu fraksi 3 dan 4 yang mempunyai aktivitas penghambatan yang kuat terhadap semua bakteri uji (Escherichia coli, Salmonella Typhimurium, Pseudomonas aeruginosa, Staphylococcus aureus, Bacillus cereus dan Listeria monocytogenes). Diantara bakteri uji yang digunakan, fraksi-fraksi sirih tersebut paling efektif menghambat Salmonella Typhimurium dengan diameter penghambatan sekitar $10 \mathrm{~mm}$ sampai $26 \mathrm{~mm}$. Hasil analisis GC-MS menunjukkan bahwa pada fraksi 3 dan fraksi 4 mengandung senyawa-senyawa kavikol; asam dodekanoat; miristat; palmitat dan oleat.

Kata kunci: antimikroba, fraksinasi, pathogen, sirih hijau

\section{PENDAHULUAN}

Salah satu tanaman herbal yaitu sirih (Piper betle Linn) telah lama diketahui dan digunakan secara turun temurun untuk pengobatan obat batuk, sakit gigi, penyegar dan sebagainya. Bagian-bagian dari tanaman sirih seperti akar, biji dan daun berpotensi untuk pengobatan tetapi yang paling sering dimanfaatkan untuk pengobatan adalah bagian daunnya. Pemanfaatan sirih dalam pengobatan tradisional ini disebabkan adanya sejumlah zat kimia atau bahan alami yang mempunyai aktivitas sebagai senyawa antimikroba.

Ekstrak sirih (Piper betle Linn) mengandung beberapa komponen aktif yang mempunyai aktivitas antibakteri, diantaranya adalah safrol dan kavibetol asetat (Arambewela et al., 2005). Hasil penelitian dari Row dan Ho (2009), fenolik merupakan komponen yang berperan sebagai bahan antimikroba sedangkan menurut Chakraborty dan Shah (2011) yang berperan sebagai bahan antimikroba dari sirih adalah sterol. Selain eugenol, komponen lain yang dapat ditemukan

*Korespondensi Penulis :

Email : suli_tari@yahoo.com pada ekstrak daun sirih adalah d-germakren, lepidosen, kariopilen, elemen, murolen, selinenol, kadine dan sineol (Periyanayagam et al., 2011), Bhattacharya et al. (2005) ekstrak sirih mengandung komponen aktif kavibetol dan alilpirokatekol. Menurut Friedman et al. (2002), komponen dalam daun sirih yang aktif sebagai bahan antimikroba adalah karvakrol, eugenol, kavibetol dan isomer eugenol. Selain hidroksikavikol, dalam daun sirih juga terdapat asam stearat dan palmitat yang mempunyai aktivitas antimikroba (Nalina dan Rahim, 2007). Penelitian dari Sugumaran et al. (2011); Gandhi dan Sugumaran (2012), selain eugenol komponen lain dalam ekstrak sirih varietas Sirugamani 1 dan vellaikodi yang berfungsi sebagai bahan antimikroba adalah 5-[2-propenil]-1,3 bensodioksol, 2-metoksi-4-[2-propenil] asetat.

Kemampuan menghambat dari masing-masing fraksi berbeda dan diduga disebabkan karena adanya kandungan senyawa kimia yang berbeda dari masing-masing fraksi tersebut. Fraksi-fraksi sirih disusun oleh beberapa senyawasenyawa yang diduga mempunyai aktivitas antimikroba. Dalam tulisan ini akan dikaji lebih lanjut aktivitas antibakteri dari fraksifraksi yang terdapat dalam ekstrak etanol sirih hijau. 


\section{BAHAN DAN METODE}

\section{Bahan}

Bahan yang digunakan dalam penelitian ini adalah ekstrak etanol daun sirih hijau. Bakteri uji yang digunakan adalah Bacillus cereus (FNCC 057), Staphylococcus aureus, (FNCC 047) Listeria monocytogenes (FNCC 0156), Pseudomonas aeruginosa (FNCC 063) dan Salmonella Typhimurium (FNCC 0734) yang diperoleh dari Pusat Antar Universitas Pangan dan Gizi UGM; Escherichia coli (ATCC) yang diperoleh dari Laboratorium Mikrobiologi Seafast (South East Asia Food and Agricultural Science and Technology) Center IPB; silika gel (Merck), nitrogen cair, media nutrien agar (NA) dan Nutiren broth (NB) dari OXOID, pelarut-pelarut etanol, kloroform dan asam asetat dari Merck.

\section{Pembuatan ekstrak sirih}

Daun sirih yang telah dikeringkan dan dihaluskan kemudian diekstraksi menggunakan etanol dengan perbandingan 1 bagian sirih dan 4 bagian etanol dengan cara dihomogenisasi dalam shaker (platform shaker Innova 2300) selama 24 jam dengan kecepatan rotasi $150 \mathrm{rpm}$. Filtrat tersebut kemudian diuapkan dalam rotavapor (Buchi, 210) pada suhu $50^{\circ} \mathrm{C}$ dan kemudian dihilangkan sisa pelarutnya dengan gas nitrogen, selanjutnya ekstrak siap digunakan untuk analisis.

\section{Persiapan bakteri uji}

Bakteri uji yang digunakan untuk pengujian aktivitas antibakteri dari ekstrak terpilih adalah Staphylococcus aureus, Escherichia coli, B. cereus, Salmonella Typhimurium, Listeria monocytogenes dan Pseudomonas aeruginosa. Sebelum dipergunakan bakteri-bakteri uji yang telah ditumbuhkan dalam media agar miring NA dan disimpan pada suhu $10^{\circ} \mathrm{C}$ tersebut terlebih dahulu disegarkan dalam media cair Nutrient broth (NB) dan diinkubasikan selama 24 jam pada suhu $37^{\circ} \mathrm{C}$.

\section{Fraksinasi ekstrak sirih (Sutedja dan Agustina, 1994)}

Fraksinasi ekstrak etanol sirih dilakukan dengan cara elusi pada kromatografi Kolom. Sebanyak 30 gram silika gel (Merck) dibuat bubur dengan menambahkan kloroform kemudian bubur kloroform tersebut dimasukkan ke dalam corong gelas dengan diameter 2,5 cm dan panjang $30 \mathrm{~cm}$, pelarut dialirkan sehingga diperoleh adsorben silika dan dibiarkan semalam. Selanjutnya ke dalam kolom tersebut ditambahkan ekstrak sirih, kemudian kolom di elusi dengan campuran eluent terpilih yang diperoleh dari hasil penelitian kromatografi Lapis Tipis (KLT) yang menghasilkan spot terbanyak yaitu campuran kloroform, etanol dan asam asetat dengan perbandingan $4: 1: 1$.

Fraksi-fraksi yang diperoleh kemudian diuapkan dan dihilangkan pelarutnya menggunakan gas $\mathrm{N}_{2}$. Volume awal fraksi yang diperoleh sebanyak $10 \mathrm{ml}$, setelah diuapkan volume fraksi yang diperoleh disamakan yaitu $3 \mathrm{ml}$.

\section{Pengujian aktivitas antibakteri (Garriga et al., 1993)}

Kemampuan aktivitas antibakteri fraksi-fraksi ekstrak sirih hijau diuji terhadap enam jenis bakteri meliputi Gram positif dan Gram negatif seperti Bacilus cereus, Staphylococcus aureus,
Listeria monocytogenes, Escherichia coli, Salmonella Typhimurium dan Pseudomonas aeruginosa. Sebelum dipergunakan isolat bakteri diaktifkan terlebih dahulu dengan terlebih dadulu ditumbuhkan dalam media cair Nutrient broth (NB) selama 24 jam.

Pengujian aktivitas antibakteri dilakukan dengan menggunakan metode difusi sumur dengan mengukur diameter penghambatan dari ekstrak tersebut terhadap masing-masing bakteri uji. Media nutrient agar $(25 \mathrm{ml}$ ) yang mengandung bakteri uji sebanyak $10^{7} \mathrm{CFU} / \mathrm{ml}$ dituangkan ke dalam cawan petri steril dan dibiarkan membeku. Setelah membeku, kemudian pada media tersebut dibuat lubang-lubang atau sumur dengan diameter $6 \mathrm{~mm}$. Ke dalam lubang tersebut dimasukkan $50 \mu \mathrm{l}$ masing-masing fraksi ekstrak sirih hijau yang diperoleh. Selanjutnya cawan diinkubasikan dalam inkubator suhu $37^{\circ} \mathrm{C}$ selama 24-48 jam.

\section{Analisis GC-MS}

Analisis dengan GC-MS (Gas Chromatography Mass Spectrofotometri, Shimadzu QP 5000) dilakukan terhadap fraksi-fraksi ekstrak sirih dengan daya hambat terkuat (fraksi 3 dan fraksi 4). Contoh $(0,2 \mu \mathrm{l})$ disuntikkan pada GC-MS (kondisi alat telah diprogram) dengan spesifikasi: kolom yang dipergunakan kolom kapiler GL Sciences TC-17 $(0,25 \mathrm{~mm} \times 30 \mathrm{~m})$, gas pembawa Helium, suhu awal $50^{\circ} \mathrm{C}$ (ditahan selama 5 menit), suhu akhir $250^{\circ} \mathrm{C}$ dengan laju kenaikan suhu $4^{\circ} \mathrm{C}$ per menit; tekanan $40-45 \mathrm{Kpa}$, suhu interface $230^{\circ} \mathrm{C}$ dengan energi ionisasi $120 \mathrm{Kv}$ (kisaran massa 33-400). Interpretasi spektrum massa hasil analisis dilakukan dengan membandingkan spektrum massa pada data base NIST 62.

\section{Analisis statistik}

Untuk mengetahui adanya perbedaan nyata atau tidak kemampuan menghambat dari masing-masing fraksi terhadap masing-masing bakteri uji dilakukan uji statistik ANOVA (SPSS 11) dan uji lanjut Duncan.

\section{HASIL DAN PEMBAHASAN}

\section{Fraksi ekstrak sirih dan aktivitas antibakteri}

Dengan menggunakan cara elusi kromatografi kolom dari ekstrak etanol sirih hijau dengan menggunakan eluen campuran kloroform, etanol dan asam asetat $(4: 1: 1)$ diperoleh sebanyak 17 fraksi. Dan dari 17 fraksi tersebut diuji aktivitas antibakterinya terhadap 6 bakteri uji. Dari hasil yang diperoleh, pada umumnya semua fraksi-fraksi etanol sirih mampu menghambat pertumbuhan satu atau beberapa bakteri uji dengan diameter penghambatan berkisar antara $10 \mathrm{~mm}$ sampai dengan $27 \mathrm{~mm}$ (Tabel 1).

Dari data diameter penghambatan yang diperoleh (Tabel 1), kemampuan penghambatan dari fraksi-fraksi sirih berbeda untuk masing-masing bakteri uji karena ada fraksi tertentu yang tidak mampu menghambat pertumbuhan bakteri (diameter penghambatan $0 \mathrm{~mm}$ ) yaitu fraksi 5 sampai fraksi 17 (kecuali fraksi 14). Kemampuan menghambat fraksi 1 dan fraksi 2 terhadap bakteri Gram positif lebih tinggi dari pada bakteri Gram 
negatif. Fraksi 3 mempunyai kemampuan menghambat yang sama antara bakteri Gram positif dan Gram negatif sedangkan fraksi 4 kemampuan menghambat pertumbuhan bakteri Gram negatif lebih tinggi dari bakteri Gram positif. Terhadap $S$. Typhimurium, semua fraksi-fraksi yang diperoleh efektif menghambat pertumbuhan bakteri tersebut.

Diameter penghambatan terendah adalah pada fraksi 5, 6, 7 dan fraksi 17 sedangkan fraksi yang mempunyai kemampuan menghambat tertinggi untuk $S$. Typhimurium adalah fraksi 3 dan fraksi 4. Terhadap bakteri uji yang lainnya seperti $B$. cereus, $E$. coli; S. aureus; $P$. aeruginosa dan $L$. monocytogenes ada beberapa fraksi yang tidak mampu menghambat pertumbuhan bakteri-bakteri tersebut. Seperti misalnya fraksi 5 , fraksi tersebut mampu menghambat pertumbuhan beberapa bakteri uji yang digunakan kecuali terhadap E. coli dan S. aureus; fraksi 6 tidak mampu menghambat pertumbuhan bakteri $S$. aureus; fraksi 7 menghambat semua bakteri uji kecuali terhadap $P$. aeruginosa sedangkan fraksi 9 hanya efektif menghambat pertumbuhan $S$. Typhimurium. Kemampuan menghambat dari fraksi 1, 2, 3 dan fraksi 4 terhadap bakteri $S$. aureus dapat dilihat pada Gambar 1.

Dengan uji statistik lebih lanjut, aktivitas antibakteri dari fraksi $1,2,3$ dan 4 terhadap pertumbuhan $E$. coli; $S$. Typhimurium dan $L$. monocytogenes memberikan perbedaan yang nyata pada taraf signifikasi $\alpha<0,5$. Fraksi 1 berpengaruh nyata terhadap pertumbuhan $S$. aureus; fraksi 1 dan 3 berpengaruh nyata terhadap pertumbuhan $B$. cereus pada taraf signifikasi $a<0,5$. Untuk bakteri $P$. aeruginosa, dengan uj statistik kemampuan menghambat pertumbuhan bakteri fraksi 1 dan 4 memberikan perbedaan yang nyata. Perbedaan kemampuan menghambat dari masing-masing fraksi ini diduga disebabkan karena adanya kandungan senyawa kimia yang berbeda dari masing-masing fraksi tersebut dan adanya efek yang saling mempengaruhi (antagonis atau sinergis) dari masing-masing komponen penyusun ekstrak sirih.

Tabel 1. Kemampuan fraksi-fraksi sirih dalam menghambat pertumbuhan bakteri uji

\begin{tabular}{ccccccc}
\hline \multirow{2}{*}{ Fraksi } & St & $\mathrm{Pa}$ & $\mathrm{Bc}$ & $\mathrm{Ec}$ & $\mathrm{Sa}$ & $\mathrm{Lm}$ \\
\hline 1 & 21 & 19,30 & 23 & 16 & 22,70 & 19,60 \\
2 & 18 & 20,30 & 25,30 & 17 & 22 & 20,30 \\
3 & 23 & 20 & 26,70 & 26 & 23 & 17,30 \\
4 & 26 & 26,60 & 25,30 & 25,60 & 23 & 12 \\
5 & 10,60 & 15 & 12,30 & 0 & 0 & 13,60 \\
6 & 10 & 11 & 11 & 10 & 0 & 10 \\
7 & 10,60 & 0 & 10,10 & 15,30 & 11,30 & 10 \\
8 & 15,30 & 17,3 & 0 & 0 & 0 & 0 \\
9 & 15 & 0 & 0 & 0 & 0 & 0 \\
10 & 14 & 0 & 12 & 11 & 0 & 0 \\
11 & 20 & 0 & 0 & 12 & 0 & 11 \\
12 & 19,60 & 0 & 21 & 23 & 14 & 10,30 \\
13 & 18 & 25,30 & 11,70 & 14,70 & 10 & 0 \\
14 & 14 & 21,70 & 18 & 15 & 11,30 & 10,30 \\
15 & 16,70 & 21,30 & 12,70 & 0 & 0 & 12 \\
16 & 18 & 21 & 0 & 0 & 0 & 0 \\
17 & 11 & 0 & 13,30 & 19,30 & 0 & 14,30 \\
\hline
\end{tabular}

Keterangan: 0: Tdak ada kemampuan menghambat (diameter penghambatan 0 $\mathrm{mm}) ; \mathrm{St}:$ S. Typhimurium; $\mathrm{Pa}: P$. aeruginosa; $\mathrm{Bc}:$ B. cereus; Ec : E. coli; Sa: $S$. aureus; Lm : L. monocytogenes

Menurut Naidu (2000), aktivitas antimikroba dipengaruhi oleh beberapa faktor diantaranya adalah komposisi kimia. Pepeljnajk et al. (2005), fraksi-fraksi yang diperoleh satu ekstrak mempunyai aktivitas antimimkroba berbeda terhadap bakteri Staphylococcus sp. dan khamir Candida lusitaniae.

Kemampuan menghambat dari fraksi-fraksi etanol sirih terhadap masing-masing bakteri uji berbeda bila dibandingkan dengan ekstrak etanol sirih. Karena ada beberapa fraksi yang tidak mampu menghambat pertumbuhan bakteri tertentu. Fraksi 3 dan 4 mempunyai kemampuan menghambat pertumbuhan bakteri uji (kecuali $L$. monocytogenes) yang lebih kuat dibandingkan dengan ekstrak etanol sirih. Ekstrak etanol sirih mempunyai kemampuan menghambat pertumbuhan S.aureus (24 mm); S. Typhimurium (19,80 mm); B. Cereus $(16,80 \mathrm{~mm})$; $P$. aeruginosa $(16,90 \mathrm{~mm})$ dan untuk $L$. monocytogenes $(16,60$ $\mathrm{mm})$.

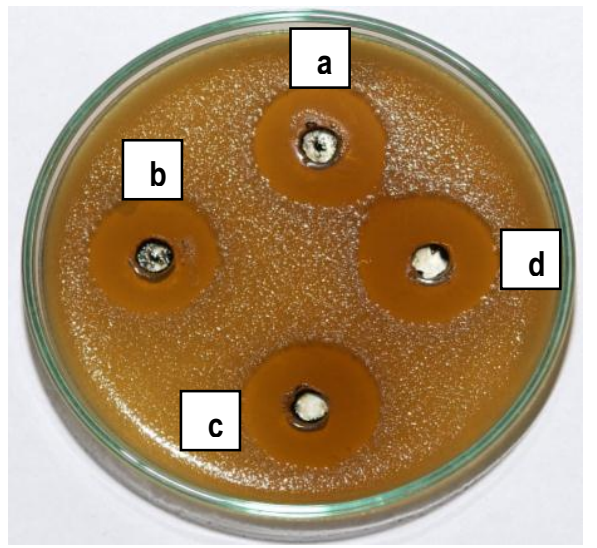

Keterangan : a: fraksi 1; b : fraksi 2; c: fraksi 3; d : fraksi 4

Gambar 1. Kemampuan fraksi sirih menghambat pertumbuhan $S$. aureus

\section{Komponen aktif dari fraksi-fraksi ekstrak sirih}

Identifikasi komponen aktif dilakukan terhadap fraksi-fraksi ekstrak sirih hijau yang mempunyai kemampuan menghambat yang tinggi terhadap semua bakteri uji khususnya fraksi 3 dan fraksi 4 .

Dengan menggunakan GC-MS dari fraksi 3 dan fraksi 4 ditemukan adanya senyawa kavikol, asam dodekanoat, miristat, palmitat dan oleat yang diduga ada hubungannya dengan aktivitas penghambatan dari fraksi-fraksi tersebut. Pada fraksi 3 kandungan komponen dari yang terendah ke tertinggi berturutturut adalah oleat $(8,9 \%)$; kavikol $(10,2 \%)$; asam miristat (16,5\%); palmitat $(24,3 \%)$ dan asam dodekanoat $(40,1 \%)$. Pada fraksi 4 , kandungan komponen dari yang terendah ke tertinggi berturut-turut adalah kavikol (8,8\%); asam miristat (10,5\%); palmitat $(21,8 \%)$; asam dodekanoat $(30,4 \%)$ dan oleat $(28,5 \%)$. Dari penelitian Nalina dan Rahim (2007), ekstrak sirih selain mengandung hidroksikavikol juga ditemukan adanya asam stearat dan palmitat yang dapat menghambat pertumbuhan mikroba. Komponen dalam daun sirih yang bersifat antimikroba adalah karvakrol, eugenol, kavibetol dan alilpirokatekol (Bhattacharya et al., 2005 dan Friedman et al., 2002). Jenie et al. (2001) dalam daun sirih ditemukan adanya kavikol, kavibetol, tanin, eugenol, karvakrol, kariofilene dan asam askorbat yang mempunyai aktivitas antibakteri. Dari hasil penelitian yang dilakukan oleh Hinton dan Ingram (2000) dan Dilika et al. (2000) asam oleat mampu menghambat pertumbuhan bakteri gram 
positif dan bersifat bakterisidal terhadap beberapa bakteri patogen dan pembusuk. Yanti et al. (2000), ekstrak daun sirih mengandung 4-alil-1,2-diasetoksi bensen dan derivat asam bensoat seperti 2,4-dimetil dan 3,5-dimetil asam bensoat yang mampu menghambat pertumbuhan bakteri pembusuk Pseudomonas fluorescens.

\section{KESIMPULAN}

Fraksinasi ekstrak etanol sirih hijau (Piper betle Linn) dengan kromatografi kolom silika gel dan pelarut campuran kloroform, etanol dan asam asetat diperoleh 17 fraksi. Dari ke 17 fraksi yang diperoleh, tidak semua fraksi mempunyai kemampuan menghambat pertumbuhan semua bakteri uji yang digunakan yaitu $E$. coli, $P$. aeruginosa, $S$. Typhimurium, $L$. monocytogenes, $S$. aureus dan B. cereus. Fraksi -fraksi 1, 2, 3 , 4 dan fraksi 14 dapat menghambat ke enam bakteri uji dengan diameter penghambatan antara $10 \mathrm{~mm}$ sampai $27 \mathrm{~mm}$. Dari ke enam bakteri uji yang digunakan, bakteri yang efektif dihambat oleh fraksi-fraksi sirih hijau berturut-turut dari yang tertinggi rendah berturut-turut adalah $B$. cereus, $S$. aureus, $P$. aeruginosa, $S$. Typhimurium, L. monocytogenes dan $E$. coli. Bakteri uji yang paling efektif dihambat pertumbuhannya oleh semua fraksi sirih adalah bakteri $S$. Typhimurium dengan diameter penghambatan antara $10-26 \mathrm{~mm}$.

Dengan GC-MS, fraksi-fraksi eksrak etanol sirih khususnya fraksi yang mempunyai aktivitas penghambatan tertinggi (fraksi 3 dan fraksi 4) mengandung senyawa-senyawa yang mempunyai aktivitas antimikroba yaitu kavikol; asam dodekanoat; miristat; palmitat dan oleat. Ekstrak dan fraksi-fraksi dari sirih dapat digunakan sebagai pengawet alami terhadap bakteri patogen dan pembusuk pangan.

\section{DAFTAR PUSTAKA}

Arambewela L, Kumaratunga KGA, Dias K. 2005. Studies on Piper betle of Sri Lanka. J Natn Sci Foundation Sri Lanka 33: 133-139. DOl: 10.4038/insfsr.v33i2.2343.

Bhattacharya S, M Subramanian, S Roychauolhury, Bauri AK, Kamat JP, Chattopadhyay S, Bandyopadhyay SK. 2005. Radioprotective property of the ethanoloc extract of piper betle leaf. J Radiat Res 46: 165-171. DOI: 10.1269/jrr.46.165.

Chakraborty D, Shah B. 2011. Antimicrobial, anti-oksidative and anti-hemolytic activity of Piper betel leaf extracts. Int $\mathrm{J}$ of Pharm and Pharmaceutical Sci 3: 192-199.

Dilika F, Bremmer D, Meyer JJ. 2000. Antibacterial activity of linoleic and oleic acids isolated from Helichrysum pedunculatum: a plant used during circumcision rites. Fitoperapia 71: 450-452. DOI: 10.1016/S0367326X(00)00150-7.
Friedman M, Henika PR, Mandrell RE. 2002. Bacterial activities of plant essential oil and some of their isolated constituent against Campylobacter jejuni, Eschericia coli, Listeria monocytogenes and Salmonella enterica. J Food Protection 65: 1545-1560.

Gandhi MS, Sugumaran M. 2012. Comparison of GC-MS analysis and antimicrobial activity of volatile oil in three varieties of Piper Betle Leaves. Int J of Pharmacy Res 1: 17.

Garriga M, Aymerich HM, Monfort JM. 1993. Bacteriocinogenic activity of lactobacilli from fermentor sausages. J Appl Bacteria 75: 142-148. DOI: 10.1111/j.13652672.1993.tb02759.x.

Hinton A, Ingram KD. 2000. Use of oleic acid to reduce the population of bacterial flora of poultry skin. J Food Protection 63: 1282-1286.

Jenie BSL, Andarwulan N, Puspitasari Nienaber NL, Nuraida L. 2001. Antimicrobial activity of Piper betle Linn extract towards foodborne pathogens and spoilage microorganisms. Http//ift.Confex.com//ift/2001/technoprogram/ paper.9068.html. [15 Juni 2004].

Nalina T, Rahim ZHA. 2007. The crude aqueous extract of Piper betle $\mathrm{L}$. and its antibacterial effect towards Streptococcus mutans. American J of Biotech and Biochemi 3: 10-15.

Naidu AS. 2000. Natural Food Antimicrobial Systems. CRC Press. London.

Pepeljnajk S, Kalodera Z, Zovko M. 2005. Antimicrobial activity of flavonoid from Pelargonium radula (Cav.) L'Herit. Acta Pharm 55: 431-435.

Periyanayagam K, Mubeen M, Sakeem, Mohamed M, Basha, Sathik S. 2011. Phytochemichal studies and GC/MS analysis on the isolated essential oil from the leaves of Piper betle var. Siguramanil 1 (SGM1). J Pharm Res 4: 24112413.

Row LCM, Ho JC. 2009. The Antimicrobial activity, mosquito larvicidal activity, antioxidant property and tyrosinase inhibition of Piper betle. J Chinese Chem Society 56: 653658.

Sutedja L, Agustina. 1994. Ekstraksi dan Fraksinasi Komponen Bioaktif Antimikroba dalam Biji dan Daun Lada. JKTI 4. Desember, 1994.

Sugumaran M, Gandhi S, Sankarnatayanen M, Yokesh M, Poornime M, Rajasekhar SM. 2011. Chemical composition and antimicrobial activity of vellaikodi variety of Piper betle Linn leaf oil against dental pathogens. Int J Pharm Tech Res 3: 2135-2139.

Sugumaran M, Pornima M, Venkatraman S, Lakshmi M, Srinivikasan S. 2011. Chemical composition and antimicrobial activity of sirugamani 1 variety of Piper betle Linn leaf oil. J Pharm Res 4: 3424-3426.

Yanti R, Suyitno, Harmayani E. 2000. Identifikasi komponen ekstrak sirih (Piper betle Linn) dari beberapa pelarut dan pemanfaatannya untuk pengawetan ikan. J Agrosains 8: 239-250. 